\title{
Utilization of Economic Rights in Music and Song Works as a Pillar of Creative Economy
}

\author{
Dwi Suryahartati ${ }^{\star}$; Nely Herlina ${ }^{\star \star}$ \\ ^ Faculty of Law, Jambi University \\ Dwisurya.efendi@yahoo.com.

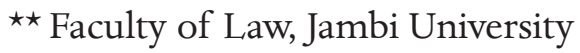 \\ Nely.herlina@gmail.com
}

\begin{abstract}
Creators and Copyright holders have an exclusive right in the form of economic rights and moral rights. Economic rights can be acquired through the payment of royalty. In order to acquire their share in the royalty, each of the creators, ccopyright holders, or the holders of related rights has to become a member of LMKN, and in return said LMKN got the authority to collect royalties from users of said artistic works. This article addressed questions: how would be the role of the Collective Management Institution in increasing the economic benefits of creators and the holders of related rights in Indonesia? How would be the mechanism of collecting royalties which is done by the Collective Management Institution according to the Act of Copyright?. In Indonesia, there are a lot of LMKNs, in which the function is to collect royalties, including collecting exclusive rights of the holders of related rights. Result performance of Collective Management Institutions has not reached its optimum capability for both creators and holders of related rights. The resulting advice of this paper is for government to create a strict payment system and a method which can also be accessed digitally by the creators.
\end{abstract}

Keywords: Intellectual Property Rights, Collective Management, Economic Rights 


\section{A. Introduction}

Intellectual Property Rights is divided into several types, in which the two biggest types are Copyright and Industrial Design Rights. Protection on these intellectual property rights can be effectively applied if all the regulations are enforced properly. Many of the standards on how far this protection should be applied can be found in various agreements which has been approved as parts of World Intellectual Property Organization (WIPO)'s activities.

World Intellectual Property Organization (WIPO) defines intellectual property as, "The legal rights which resulted from intellectual activities in the industrial, scientific, literary, or artistic field." Thomas W. Dunfee and Frank F. Gibson define Intellectual Property as a physical manifestation of a practical, creative, or artistic idea and certain ways to acquire a protection over it. ${ }^{1}$

Intellectual Property Rights is a right of ownership which lies in the scope of technology and science, as well as arts and literatures. The rights of ownership shall be applied not to the product itself, but instead over the result of the intellectual ability of the human, in which it can be in the form of ideas. Intellectual Property Rights protects the usage of said ideas, and any information that contains any commercial or economic values. ${ }^{2}$

Intellectual Property Rights became very important with the increase of industrial and trading activities. This can be seen from 2 (two) general categories of Intellectual Property Rights, which are:

1. Intellectual Property Rights on industrial sector;

2. Intellectual Property Rights on Copyright and related rights to Copyright. According to literatures and science, there are two rights being included in Copyright, which are:

a) Economic rights; Defines as a right with monetary value, usually is eligible to be shifted over and to be exploited economically.

1 Ridwan Khairandy, Pengantar Hukum Dagang, Yogyakarta: UII Press, 2006, p. 226.

2 Muhamad Djumhana \& R. Djubaidillah, 2003, Hak Milik Intelaktual, Sejarah, Teori, dan Prakteknya di Indonesia, Bandung: Citra Aditya Bakti, p. 21. 
b) Moral rights; Defines as a right which emerged as the result from the existence of individuality between the creation and the creator itself, or can also be in the form of an integrity from the creator. ${ }^{3}$

The recognized principles of Copyright are:

1. Principle of originality;

2. Principle of novelty;

3. Principle of tangibility;

4. Copyright emerged from a direct creation.

According to the Act of Copyright (UUHC), the creation which is protected by this law are in the scope of science, literatures, and arts. It includes:

1. Books, computer programs, pamphlets, layouts, published papers, and other papers;

2. Lectures, discourses, speeches, and any other similar creations;

3. Props or models which were made for the purpose of education and science;

4. Songs/music with or without text (lyrics);

5. Drama/musical drama, dance choreography, puppetry, and pantomime;

6. All forms of fine arts (paintings, pictures, sculpturing, calligraphies, statues, collages, other applied fine arts);

7. Architectures;

8. Maps;

9. Art of batik;

10. Photography;

11. Cinematography;

12. Translations, tafsir, adaptations, book of collections of ideas (bunga rampai), databases, and any other derivative works.

The work of songs and music is one of several types of artistic works that is protected by the Act of Copyright, in accordance to Article 40 in Act No. 28 of 2014 About Copyright (UUHC). The work of songs and music is defined as the whole creation of work consisted of

3 Suyud Margono, Aspek Hukum Komersialisasi Aset Intelektual, CV. Nunasa Aulia, Bandung, 2010, p. 15. 
elements of a song or melody, lyrics, including the notes, in a sense that the said song or music is considered as a whole artistic work. Copyright is regulated through Act No. 28 of 2014 about Copyright (UUHC).

Creators and Copyright holders hold the exclusive rights in the form of economic rights and moral rights. According to Article 8 Paragraph (1) in Act No. 28 of 2014 about Copyright (UUHC), the composer of a song has the economic rights to announce or reproduce permit to other party to do such rights. In order to collect royalty from creators and/or holders of related rights, the Act of Copyright (UUHC) specified the existence of National Collective Management Institution (LMKN). LMKN is a non-profit legal entity which has been given an authority by Copyright holders and/or holders of related rights to manage the economic rights in collecting and distributing royalties.

To be able to acquire their share in the royalty, each of the creators or Copyright holders or the holders of related rights has to become a member of LMKN, so in return said LMKN has the authority to collect royalties from users of said artistic works. Royalty is a form of payment or reward given to creators and/or Copyright holders over the utilization of the economic rights or related rights of a creation or a product. Utilization of Copyright should be done legally. It is stated in Article 10 of the Act of Copyrights (UUHC) that: A manager (person in charge) shall not allow any sale and/or duplication of any goods that were produced with any kinds of Copyright and/or related rights infringement in their shop/trading places.

1. Through radio broadcasts, pubs, karaokes, restaurants, aviation services, hotels, gas stations;

2. Through television broadcasts in a way that said creation could be heard and watched by other people;

3. Through printed medias, such as newspapers, tabloids, magazines, posters;

4. Through direct/live broadcasts and/or being broadcasted through any kinds of electronic medias;

5. Through an announcement of the creation by plastering said 
announcement on specific places (such as billboards or posters) so it could be read and saw by other people.

This means that any form of utilization over Copyright requires payment of its royalty. For example, usage of music in cafes, restaurants, hotels, flight/airline services, gas stations, supermarkets, karaoke places, television broadcasts, radio broadcasts, et cetera. In order to be able to collect royalties over this announcement of said creation, Collective Management Institution (LMK) is required to hold the authority given by creators, Copyright holders, and holders of related rights. Any kind of public places' owners or any entrepreneurs who are using this creation are also obligated to acquire a Licensing Agreement regarding said creation. Recently, a Memorandum of Understanding (MoU) was created to be used as reference for the hotel industry in Indonesia in general, and reference for the Association of Indonesian Hotels and Restaurants (Perhimpunan Hotel dan Restoran Indonesia or PHRI) in particular, in order for them to carry out and apply regulation in Act No. 28 of 2014 about Copyright (UUHC). This MoU was also created to replace the Ministerial Decree of Ministry of Justice and Human Rights of Republic of Indonesia No. HKI.2.OT.03.01-02 of 2016 about The Ratification of Royalty Rates for The User Who Commercially Utilizes a Creation and/ or Related Rights of a Product Over Music and Songs (Keputusan Menteri Hukum dan Hak Asasi Manusia Republik Indonesia No. HKI.2.OT.03.01-02 Tahun 2016 tentang Pengesahan Tarif Royalti Untuk Pengguna Yang Melakukan Pemanfaatan Komersial Ciptaan dan/atau Produk Hak Terkait Musik dan Lagu) which was published on May 20th, 2016. This Ministerial Decree is the Ruling of National Collective Management Institution about Royalty Rates for Hotel \& Hotel Facilities which was issued on May 12th, 2016. ${ }^{4}$

The existence of the Act of Copyright (UUHC) is very important in order to give a proper protection to all parties including creators, Copyright holders, and holders of related rights, so that all of these parties would be able to receive their rights. This is why the

4 National Workshop of PHRI 1, Westin Hotel, Nusa Dua, Bali, on November 7 th, 2016. 
Collective Management Institution (LMK) has to be able to perform its function to its optimum ability. It also means that if the eligible parties received their economic rights (in the form of payment of royalties), then it would ensure their welfare and motivated them to make their next work of creation.

\section{B. Utilization of The Economic Rights of Creators and Holders of Related Rights Through Collective Management Institutions}

Act No. 19 of 2002 was the law effectively applied to regulate about royalty before Act No. 28 of 2014 was issued, although this predecessor law has created many problems in its application. This was proven by the low income received by creators and holders of related rights in Indonesia. Act No. 28 of 2014 was issued with the intention to rectify the mistakes and drawbacks of Act No. 19 of 2002. In this Act of Copyright (UUHC), the rights over songs and music got paid more attention than in the predecessor law.

In regards of current cases, Act of Copyright also stated on how to settle Copyright disputes. These disputes could be settled through alternative dispute resolution and arbitration before bringing the case into court. As stated in Article 95 Paragraph (1) of Act of Copyright (UUHC):

1. Copyright dispute resolution can be done through alternative dispute resolution, arbitration, or court.

2. The court whom has the power, as intended in paragraph (1), is the commercial court (pengadilan niaga).

3. Any other court outside of commercial court, as intended in paragraph (2), holds no power over the handling of any copyright dispute.

4. Outside of copyright infringement and/or infringement of related rights in the form of piracy, as long as all of the disputing parties' existences are known and/or located in the territory of Republic of Indonesia, said parties have to go through a dispute resolution via mediation before filing any criminal charges. 
The Act of Copyright (UUHC) also gives protection to creators and holders of related rights in other ways, such as:

A. Regulation over the record of related rights of said product in Article 64 of the Act of Copyright (UUHC);

B. Obligation to pay the royalty to creators through Collective Management Institution (LMK) is enforced upon users whom utilize said copyright and related rights, this is regulated through Article 87 of the Act of Copyright (UUHC);

C. Regulations of Collective Management Institutions (LMK) in the field of songs and/or music in which represents the interests of holders of related rights in Article 89 of the Act of Copyright;

D. Regulations regarding possible criminal punishment to be imposed on the case of any infringement over the economic rights of the owner of any related rights in Article 116 to 118 of the Act of Copyright (UUHC). ${ }^{5}$

Music industry in Indonesia is developing very rapidly. It is also supported by the fact that music is one of the biggest foundation in the creative industry, which is very labor intensive. There is a high potential of the collection of royalties, which is also equivalent with the development of the Collective Management Institution (LMK) which has the task of collecting said royalties. There are several developing LMKs in Indonesia. In music sector, there are several LMKs, such as KCI (Karya Cipta Indonesia), RMI (Royalti Musik Indonesia), WAMI (Wahana Musik Indonesia), ASIRI (Asosiasi Industri Rekaman Indonesia), ASPRINDO (Asosiasi Produser Rekaman Indonesia), PRISINDO (Performers Rights Society of Indonesia), and GNP (Gema Nada Pertiwi).

Countries which ratified the regulations regarding Intellectual Property Rights, especially regarding copyright, would be subjected to adhere to the international conventions about Intellectual Property Rights. Country would always intervene in the case of fulfilment of the exclusive rights of creators and holders of related rights.

5 Monica Suhayati, Pelindungan Hukum Terhadap Hak Ekonomi Pemilik Hak Terkait Dalam Undang-Undang Nomor 28 Tahun 2014 Tentang Hak Cipta, Jurnal Negara Hukum, Vol. 5,No.2, 2014. 
Of course this would be done through developing a good and clear mechanism of collecting royalties via LMK. Although there are also some countries which give a liberty to its LMKs to regulate the mechanism of collecting economic rights on their own. On the contrary, China is one of the countries that hasn't given such liberty to its LMKs and instead, holding a full control over all of the existing Collective Management Institutions (LMK) in the country. A country's intervention is needed in order to avoid any unhealthy competition between LMKs and also to give a legal certainty over the status of said Collective Management Institutions (LMK) itself.

Song and music composers, singers, musicians, performers, phonograph producers, and all owners of related rights needed royalties as the reward over their creations in order to ensure the sustainability and innovation of their creations. This is not a small issue because music has become a big part of creative economy, and it should be an important foundation of Indonesia's creative economy sector.

Howkins defines Creative Economy as an economic activity in which both its inputs and outputs are in the form of Ideas. In a shorter explanation, the essence of creativity is the existence of ideas. This is why it can be seen how with only some form of ideas, a creative person could gain a relatively high income from it. Of course in this case, what referred to be an idea is an original work which can be protected by Intellectual Property Rights. ${ }^{6}$

Creative economy has become a source of new hope to increase the level of income. Music is one of the sector which was placed under the Directorate of Development of Performing Arts and Music Industry (Direktorat Pengembangan Seni Pertunjukan dan Industri Musik), which is part of the General Directorate of Arts and CultureBased Creative Economy (Direktorat Jenderal Ekonomi Kreatif Berbasis Seni dan Budaya) of Ministry of Tourism and Creative Economy (Kementerian Pariwisata dan Ekonomi Kreatif). There are two things to be considered in order to see music industry as a potential sector with high economic value. First, music industry is a labor-intensive

$6 \quad$ Ibid, p. 54. 
industry. This is caused by the fact that a good performance of music, whether it was a recording or a live performance, needs the support of a lot of people. For example, recording of an album. Aside from the singer and the band players, this process also needs a music producer, a music director, a sound engineer, up to an album cover designer. Another example, for a live performance it would also need several other people with various tasks aside from the performers themselves. These people usually called as the people who works behind the scene, such as show director, lighting engineer, up to the driver who drives the show performers to the location of the performance. This is why music industry is a sector that absorbs a lot of labors. Second, music industry is a fluid industry. This means that music industry can easily entered and spread into many other industries. Music business is proven to be existed as parts of many other businesses. As an example, telecommunication industry needs music in order for its telecommunication channels to be packed with visitors whom wanted to get access into the music entertainment. Another example is that banking industry is using the prestige of fun music which is familiar to the younger generation in order to attract customers and persuading to open an account in their bank. This strategy is used because of the fact that not many people would easily change their bank account, especially if they have been using it for a long time since they were younger. There is also the example of restaurants using music to make its customer stays longer in their restaurant, and in return there is a high chance that these customers would order more food. From these examples, it can be seen how fluid music industry is, and it has been proven that it can easily entered and spread into many kinds of existing business. If this potential of music is understood since its early spread, then it is possible to push people's aspiration to work in the music business in various professions it got and not only to become a band player. The profession of being a band manager or a sound engineer of a performance is also a profession with a high level of income. ${ }^{7}$

7 Faisal Afiff, “PILAR-PILAR EKONOMI KREATIF”, (12 April 2012); http: / / www.feb.unpad.ac.id/id/arsip-fakultas-ekonomi-unpad/opini/2198-pilar- 
As explained in the paragraph above, this is why singers, actors, actresses, song composers, and any other related performers in the music field need some form of innovation. The problem is that this form of artistic work can be easily copied and pirated, especially with the existence of the internet, and any kinds of intellectual property rights infringement would kill off the innovation in this field. The development of creative economy in Indonesia collectively needed to be integrated into the economic system as a whole, so that Indonesia would have an economic security as well as cultural resilience.

For example, the role of Karya Cipta Indonesia (KCI) as a Collective Management Institution (LMK) of copyright. According to Dhiko Herlambang, its role to perform its duty in collecting royalties has fit accordingly into the regulation. ${ }^{8}$ Another opinion came from Enteng Tanamal who stated otherwise. He stated that there are difficulties in regards to collecting royalties in Indonesia, considering geographical factors and how massively dispersed these works are throughout Indonesia. ${ }^{9}$

Based on my observation, there aren't many cases of copyright disputes regarding royalties existing. This is presumably happened not because there isn't any dispute happened, but it is because many creators and holders of related rights have given their licenses to Collective Management Institutions (LMK) and this is causing them to be careless over their own rights or even not understanding at all about the protection given to them in regards of their economic rights. If a dispute happened and cannot be resolved through mediation, the offender can be prosecuted criminally, which according to the Act of Copyright (UUHC) it's a Klacht Delict (also known as Antragsdelikt or Delik Aduan). This means that copyright infringement is included in a category of offensewhich cannot be prosecuted without a complaint by the victim. The concept of Klacht Delict means that the prosecu-

pilar-ekonomi-kreatif, accessed 14 Jan 2018

8 Dhiko Herlambang, Peran Karya Cipta Indonesia Dalam Perlindungan Hak Cipta Lagu yang Digunakan Secara Komersial, Skripsi, Fakultas Hukum Universitas Muhammadiyah Surakarta, p.1,2016.

9 Interview with Enteng Tanamal (Founder of PAPPRI dan ex-Manager of KCI), Ambon, Maluku, During Rakernas PAPPRI, November 2016. 
tor would only prosecute a case only if the victim of the said offense filed a complaint against any action that costed them any distress and/ or any loss or damage. According to Tony Pulo from KCI Foundation (Yayasan Karya Cipta Indonesia), the existence of Klacht Delict only slowed the enforcement of the law over such cases. This is caused by the fact that Klacht Delict means that the enforcement of the law is being conducted passively, because it would only be enforced with a filed complaint from the victim. This is incompatible with the fact that there are a lot of creators who are suffering from damage of loss but due to many factors such as lack of understanding, reluctance to deal with law enforcement, and/ or lack of facilities, these victims are reluctant or unable to file a complaint against these offense. ${ }^{10}$

Karya Cipta Indonesia (KCI) as one of the Collective Management Institutions (LMK) existed in Indonesia has their own way in collecting royalties from any business places which publicized the works of music and songs for commercial purposes. In accordance to law, KCI reserved the right to collect royalties from any business owner whom utilizes KCI's members' artistic works. In Yogyakarta, a single-room of a karaoke place would usually pay Rp. 720.000,- (seven hundred and twenty thousand rupiahs) per year, and then it would be multiplied by the amount of room existing in said karaoke place. ${ }^{11}$

\section{Collective Management Institution's Mechanism on Collecting Royalties in Indonesia}

Before we discuss about the mechanism, we should first take a look on the position of the Collective Management Institutions (LMK) in the Act of Copyright (UUHC). How actually is the position of LMK in Indonesia? There are parties who felt that LMK does not actually have any authority to "quote" any profit from the users of a copyrighted artistic work because these said parties felt that they don't

10 Loc. Cit, p. 546.

11 Waspiah, Efektifitas Lembaga Manajemen Kolektif Dalam Memungut Royalti Berdasarkan Undang-undang No. 28 Tahun 2014 Tentang Hak Cipta, Prosiding Seminar Nasional Multi Disiplin Ilmu \& Call Papers UNISBANK (SENDi_U) No. 2, 2016, p. 546. 
have any business with any LMK. The Act of Copyright (UUHC) explicitly stated that the position of the LMK is to help creators, copyright holders, and/or holders of related rights, that is only if these LMK functions well accordingly to its true tasks and the country in which they existing acknowledged their existence. The authority of LMK to do its duty is recognized and acknowledged by the law. In order to do its duty, an LMK has to get a Decree (Surat Keputusan or SK) from the Ministry of Justice and Human Rights (Kementerian Hukum dan HAM) of Republic of Indonesia. Currently there are 6 LMKs which already acquire its decree from the Ministry of Justice and $\mathrm{Hu}-$ man Rights of Republic of Indonesia. These 6 LMKs are divided into 2 groups, Collective Management Institutions (LMK) of Copyrigh; And Collective Management Institutions (LMK) of Related Rights. The LMKs grouped into LMK of Copyright are LMK Karya Cipta Indonesia (KCI), LMK Wahana Musik Indonesia (WAMI), and LMK Royalti Anugrah Indonesia (RAI); While the LMKs grouped into LMK of Related Rights are LMK PAPPRI, LMK Sentra Lisensi Musik Indonesia (SELMI), and LMK Anugrah Royalti Dangdut Indonesia (ARDI).

Article 1 No. 22, Collective Management Institution (LMK) has already existed in the definition. It is stated:

Collective Management Institution is a non-profit legal entity which has been given an authority by Creators, Copyrights Holders and/or the Holders of Related Rights to manage their economic rights in legally collecting and distributing the royalties.

Article 87

(1) To be able to acquire their share in the royalty, each of the Creators, Copyrights Holders, and the Holders of Related Rights has to become a member of a Collective Management Institution in order to collect a reasonable reward (payment) from users whom utilize the Copyright and Related Rights in the form of commercial public service.

(2) Users of Copyright and Related Rights whom utilize said rights, as intended in paragraph (1), are required to pay Royalty to Creators, Copyright Holders, or Holders of Related Rights, through the Collective Management Institutions. 
(3) Users, as intended in paragraph (1), are required to make an agreement with the Creative Management Institution, in which this agreement contained the obligations of users to pay Royalty over Copyright and Related Rights being utilized.

(4) Any form of commercial utilization of the Creation and/or Product of Any Related Rights by the user would not be considered as an infringement of law, as long as said user have done and fulfilled their obligations according to the agreement made with the Collective Management Institution.

Article 88 regulates how a Collective Management Institution (LMK) should acquire a Ministerial Decree in order to operate: Article 88

(1) A Collective Management Institution, as intended in Article 87 paragraph (1), is required to submit an application for an operational permit to the Ministry.

(2) An operational permit, as intended in Article 87 paragraph (1), has to comply to these requirements:

a. Is a non-profit legal entity in Indonesia;

b. Is given an authority by Creators, Copyright Holders, or Holders of Related Rights to retrieve, collect, and distribute Royalty;

c. Has at least 200 (two hundreds) endorser members of Creators for a Collective Management Institution in the work field of songs and/or music which represents the interest of Creators, and at least 50 (fifty) member for a Collective Management Institution which represents Holders of Related Rights and/ or any other Copyright objects;

1. Has the purpose of retrieving, collecting, and distributing Royalties; and

2. Is capable to retrieve, collect, and distribute Royalty to Creators, Copyright Holders, or Holders of Related Rights.

3. A Collective Management Institution which has not acquired an operational permit from the Ministry, as intended in paragraph (1), shall not be allowed to retrieve, collect, and distribute the Royalty.

By looking at the two articles explained above, it looks like these two articles are sufficient in regulating the Collective Management 
Institutions (LMK), until the word "national" appeared in Article 89 paragraph (1) but then disappeared again in paragraph (2), (3), and (4).

Article 89

(1) 2 (two) types of National Collective Management Institutions are formed to manage the Royalty of Copyright in the work field of songs and/or music, which each of these types represents these things:

(2) The interest of Creators; and

(3) The interest of the Holders of Related Rights.

(4) Both of these Collective Management Institutions, as intended in paragraph (1), has the authority to retrieve, collect, and distribute Royalties from commercial Users.

(5) To be able to collect Royalties, as intended in paragraph (2), both types of Collective Management Institutions are required to coordinate and determine the amount of Royalty, in which these things become a right owned by each of these Collective Management Institutions in accordance to the principle of prevalence in the practice based on justice.

(6) Clauses regarding the guidelines on how to determine the amount of Royalty is set by the Collective Management Institution, as intended in paragraph (1), and is validated by the Ministry.

Article 121 particle (g) Transitional Provisions mentioned as such:

"Any professional organizations or similar institutions with any kinds of names which held the function to collect, manage, and/or distribute Royalties before the issuance of this Act has the mandatory to adjust and change its status into Collective Management Institution within a maximum period of 2 (two) years since the issuance of this Act."

Article 89 paragraph (3) which stated:

To be able to collect Royalties, as intended in paragraph (2), both types of Collective Management Institutions are required to coordinate and determine the amount of Royalty, in which these things become a rights owned by each of these Collective Management Institutions in accordance to the principle of prevalence in the practice based on justice. 
Article 88 paragraph (1) stated that a Collective Management Institution (LMK), as intended in Article 87 paragraph (1), is required to submit an application for an operational permit to the Ministry, and paragraph (3) stated that a Collective Management Institution (LMK) which has not acquired an operational permit from the Ministry, as intended in paragraph (1), shall not be allowed to retrieve, collect, and distribute the Royalty.

Article 93

Further provisions regarding guidelines on how to apply and the issuance of the operational permit, and the evaluation on said Collective Management Institution is regulated with a Ministry Decree.

The duty of a Collective Management Institution (LMK) is to coordinate and supervise the collection of royalties done by National Collective Management Institutions (LMKN) below it. Public places or places which uses music such as cafés, karaoke places, and artistic performances are expected to pay royalties in accordance to regulations set by these institutions. These institutions are expected to be able to collect, manage, and then distribute royalties back to creators and then to holders of related rights. The formation of National Collective Management Institutions ( $\mathrm{LMKN}$ ) is expected to help creators in receiving their rights, especially economic rights which should be able to be feasibly received. Users who utilize the economic rights of Copyright and Related Rights should pay Royalties to Creators, Copyright Holders, or Holders of Related Rights, through Collective Management Institutions.

In order to operate, a Collective Management Institution (LMK) should comply with these requirements:

1. Is a non-profit legal entity in Indonesia;

2. Is given an authority by Creators, Copyright Holders, or Holders of Related Rights to retrieve, collect, and distribute the Royalty;

3. Has at least 200 (two hundreds) endorser members of Creators for a Collective Management Institution in the work field of songs and/or music which represents the interest of Creators, and at least 50 (fifty) member for a Collective Management Institution 
which represents Holders of Related Rights and/or any other Copyright objects;

4. Has the purpose of retrieving, collecting, and distributing Royalties; and

5. Is capable to retrieve, collect, and distribute the Royalty to Creators, Copyright Holders, or Holders of Related Rights.

The mechanism on how to collect royalties can be seen from the mechanism set by LMK Karya Cipta Indonesia (KCI). In general, it begins with creators or copyright holder or song/music's rights holders giving the authority to $\mathrm{KCI}$ in order to collect royalties over any kinds of commercial announcement or utilization of said copyright by other people. The next step is to distribute collected royalties to the feasible parties, after it was deducted by the administration fee. In this case, the amount of royalty paid by the licensee is set by KCI, as they have been given the authority by the creator. This then allows the licensee, as the party who received a permit from the creator, to exploit the creation in accordance to the agreement made beforehand.

Another thing regarding the function of Collective Management Institution (LMK) can be seen from LMK Penerbit Karya Musik Pertiwi (PMP). The song of Bengawan Solo was composed by Gesang, and it has been exploited in many other forms of creations. Gesang, as the composer of the song and the copyright holder, appointed LMK PMP to collect royalties for the licensing agreement of this song (Bengawan Solo). The royalties collected by LMK PMP then distributed back to Gesang, in which the formulation on how to calculate the amount being paid back to Gesang is as such:

\footnotetext{
$\mathrm{TR}=\mathrm{JL} / \mathrm{TL} \times \mathrm{R} \times \mathrm{PPD}$

Annotation:

TR : Total amount of Royalties

JL : : Total amount of licensed songs

TL : Total amount of songs in an album (Maximum of 12)

R : Royalty Rate (6\%)

PPD : Published Price for Dealer, which can be calculated as such: $(72 \% \mathrm{x}$ retail price $)-($ VAT + ASIRI Administration fee $)$
}

The TR (total amount of royalties) then multiplied by the mini- 
mum warranty and added by $10 \%$ rate of VAT (Value-Added Tax or PPN). If there are 12 songs in one album, then the calculation of the advance royalty can be calculated by counting the Total Amount of Royalties for 12 songs (as seen in the formulation above), and for the rest it can be calculated using the formulation as such:

TR $-\{$ TR $\times(J L-12) \times 2,5 \%\}$

This can be seen concretely in the example of the song Bengawan Solo being included in Rafi's album titled Can't Stop the Beat, produced by PT RAF Production and PT Aquarius Musikindo. In this case, for the usage of the song of Bengawan Solo, PT RAF Production and PT Aquarius Musikindo made an agreement with LMK PMP, as the LMK who has been appointed by the copyright holder of the song, in order to be able to license the song (Bengawan Solo) and include it in the album. This album included the track list of 10 songs in the media of cassette tape, being sold for the price of Rp. 20.000 (twenty thousand rupiahs) with minimum warranty of 10.000 pieces. With those data, the royalties can be calculated as such:

$$
\begin{aligned}
& \mathrm{TR}=110 / \times 6 \% \times(72 \% \times \text { Rp. 20.000) }-(\text { Rp. } 800+\text { Rp. 60) } \\
& =110 / \times 6 \% \times(\text { Rp. 14.400) }-(\text { Rp. 860) } \\
& =110 / \times 6 \% \times(\text { Rp. 13.540) } \\
& =110 / \mathrm{x} \text { Rp. } 812,40 \\
& =\text { Rp. } 81,24 \\
& \text { Minimum warranty }=10.000 \text { pcs x Rp. } 81,24 \\
& =\text { Rp. } 812.400 \\
& \operatorname{VAT}(\mathrm{PPN}) 10 \%=\underline{\text { Rp. } 81.240}+ \\
& =\text { Rp. } 893.640
\end{aligned}
$$

From the calculation above, it can be seen that the total amount of royalties should be paid by PT RAF Production and PT Aquarius Musikindo to LMK PMP for the utilization of the song Bengawan Solo in the album mentioned above if Rp. 893.640 (eight hundreds ninety three thousands six hundreds and forty rupiahs). After this royalties being paid to LMK PMP, then LMK PMP will manage said royalties before distribute it back to the creator (composer). ${ }^{12}$

12 Yudhistiro Tri Prakoso, Implementasi Pembayaran Royalti Lagu Bengawan Solo Untuk Kepentingan Komersial Ditinjau dari Perspekrif UU No. 19 Tahun 2002 tentang Hak Cipta, Tesis, Magister Kenotariatan Universitas 
The calculation above is a simulation if the creator give their rights to exploit their creation to other party and let the other party to handle everything regarding the exploitation and utilization of their creation. There are also times when creator or owners of any related rights chose to make the licensing agreement individually with the LMK, as intended in the Act of Copyrights (UUHC).

\section{Conclusion and recommendation}

\section{Conclusion}

The Collective Management Institutions (LMK) that are existing in Indonesia have not reach its maximum potential in doing its tasks and functions to collect royalties from creators and holders of related rights. Creators and holders of related rights still haven't felt the maximum economic benefits from their artistic work of music and songs.

There is still no mechanism and uniform system on how to distribute the royalties back to creators and holders of related rights. Each of the LMK has its own payment system according to the licensing agreement and power of attorney which made by each of the LMKs. This make it seems that all of the LMKs in Indonesia are competing with each other to be able to get the licensing agreement from creators and holders of related rights. Aside from that fact, the amount being collected over the utilization of music and songs in public places and commercial places (such as karaoke places, hotels, restaurants, malls, and any other commercial places) is still in need to be reviewed in order to ensure there is true enforcement of justice.

\section{Suggestion}

The government needs to create a strict and limiting regulation in regards to the system and mechanism of royalties collection by the LMKs existing in Indonesia as soon as possible. If necessary, the government should also created only one LMK, which acted as the Na-

Diponegoro, Hal. 150-151, 2008. 
tional Collective Management Institution (LMKN) that regulates the collection of royalties in order to prevent the practice of double royalty collection against the users. The government also needs to fix the regulation on the process of how to license music, because the existence of any kinds of stimulation and motivation given by the government to the music industry will help to create and grow the education of music business. Lastly, the most important this is to create a management of national archive of collection of music.

\section{Bibliography}

Djumhana, Muhamad dan R. Djubaidillah, 2003, Hak Milik Intelaktual, Sejarah, Teori dan Prakteknya di Indonesia, Bandung: Citra Aditya Bakti.

Herlambang, 2016, "Dhiko, Peran Karya Cipta Indonesia Dalam Perlindungan Hak Cipta Lagu yang Digunakan Secara Komersial," Undergraduate Thesis, Faculty of Law Universitas Muhamadiyah Surakarta.

http:/ / www.feb.unpad.ac.id/id/arsip-fakultas-ekonomi-unpad/ opini / 2198-pilar-pilar-ekonomi-kreatif.

Margono, Suyud, 2010, Aspek Hukum Komersialisasi Aset Intelektual, CV. Nunasa Aulia, Bandung.

Prakoso, Yudhistiro Tri, 2008, "Implemntasi Pembayaran Royalti Lagu Bengawan Solo Untuk Kepentingan Komersial ditinjau dari Perspekrif UU No. 19 Tahun 2002 tentang Hak Cipta,” Master Thesis, Notary Master Program, Universitas Diponegoro.

Suhayati, Monika, 2014, "Pelindungan Hukum Terhadap Hak

Ekonomi Pemilik Hak Terkait Dalam Undang-Undang Nomor 28 Tahun 2014 Tentang Hak Cipta," Jurnal Negara Hukum, Vol. 5 , No.2.

Waspiah, 2006, "Efektifitas Lembaga Manajemen Kolektif Dalam Memungut Royakti berdasarkan Undang-undang No. 28 Tahun 2014 Tentang Hak Cipta," Proceedings of National Seminar of Multi Sciences \& Call Papers UNISBANK (SENDi_U) II. 